\title{
Estradiol treatment prevents injury induced enhancement in spinal cord dynorphin expression
}

\section{Daya S. Gupta and Charles H. Hubscher*}

Department of Anatomical Sciences and Neurobiology, University of Louisville, Louisville, KY, USA

Edited by:

Alexander Rabchevsky, University of Kentucky, USA

\section{Reviewed by:}

Virginie Tolle, INSERM, France

Tom Cunningham, University of North

Texas Health Science Center, USA

\section{*Correspondence:}

Charles H. Hubscher, Department of Anatomical Sciences and

Neurobiology, University of Louisville, Louisville, KY 40292, USA.

e-mail: chhubs01@/ouisville.edu
Administration of the ovarian steroid estradiol in male and female animals has been shown to have neuromodulatory and neuroprotective effects in a variety of experimental models. In the present study, spinal tissues from dermatomes just above (T5-T7, at level) a severe chronic spinal cord injury (SCl) at T8 were analyzed for expression levels of prodynorphin (PRDN) and phospho-(serine 369) к-opioid receptor (KOR-P) in $17 \beta$ estradiol (EB)- and placebo-treated adult male rats. Dynorphin was targeted since (1) it has previously been shown to be elevated post-SCl, (2) intrathecal injection of dynorphin produces several of the same adverse effects seen with a $\mathrm{SCl}$, and (3) its increased expression is known to occur in a variety of different experimental models of central neuropathic pain. A significant elevation of extracellular levels of both PRDN and KOR-P in the placebo-treated SCI group relative to uninjured surgical sham controls was found in spinal tissues above the injury level, indicating increased dynorphin levels. Importantly, the EB-treated SCl group did not show elevations of PRDN levels at 6 weeks post-injury. Immunohistochemical analysis of at level tissues revealed that EB treatment significantly prevented a post-SCI increase in expression of PRDN puncta co-labeling synapsin I, a nerve terminal marker. The dynorphincontaining terminals co-labeled vesicular glutamate receptor-2 (a marker of glutamatergic terminals), a finding consistent with a non-opioid basis for the adverse effects of dynorphin. These results support a beneficial role for EB treatment post-SCl through a reduction in excessive spinal cord levels of dynorphin. Studies manipulating the timing of the EB treatment post-injury along with specific functional assessments will address whether the beneficial effects are due to EB's potential neuromodulatory or neuroprotective action.

Keywords: spinal cord injury, neuropathic pain, dynorphin, estradiol

\section{INTRODUCTION}

The effect of circulating blood levels of $17 \beta$-estradiol on the development of central neuropathic pain in a model of severe chronic spinal cord injury (SCI) at T8 has been a focus of recent studies in our laboratory. We have previously reported that the proportion of ovariectomized (ovx) SCI female rats and placebo-treated SCI males displaying pain-like behaviors (allodynia) evoked by light touch or pressure applied to sensitive dermatomes (T5-T8) up to 6 weeks post-injury (67 and 75\%, respectively; Hubscher et al., 2010) was similar to our previous studies on SCI males (69\%; Hubscher and Johnson, 1999, 2006). In contrast, significantly fewer estrous cycling SCI female rats and $17 \beta$-estradiol (EB) treated SCI male rats showed sensitivity to touch at level (26 and 30\%, respectively) up to 6 weeks post-SCI (Hubscher et al., 2010). Thus, our prior studies demonstrate a positive outcome on the development and/or maintenance of at level (T5-T8) allodynia after treatment with subcutaneous EB pellets that were implanted prior to the injury. Note that several different research groups have shown beneficial functional outcome of EB treatment in SCI rodent models for locomotor function, which several studies have shown is due in part to a reduction in apoptotic cell death (Yune et al., 2004; Chaovipoch et al., 2006; Sribnick et al., 2006; Ritz and Hausmann, 2008; Kachadroka et al., 2010).
The purpose of the present study is to begin investigating whether EB acts to diminish the observed sensory disturbances at level post-SCI by acting upon some of the adverse neuromodulatory changes that disrupt normal homeostatic mechanisms in the tissues just above the level of lesion (region of cord supplying the hypersensitive dermatomes). Dynorphin, an endogenous $\kappa$ opioid agonist (Chen et al., 2007), has been chosen for the study of adverse at level neuromodulatory changes because high tissue levels of dynorphin in spinal cord has been shown in different experimental models of neuropathic pain, including nerve injuries by spinal nerve ligation (SNL) at L5, L6, and S2 (Malan et al., 2000; Lai et al., 2006), inflammatory pain models in rats induced by injections of the complete Freund adjuvant (CFA; Millan et al., 1985; Calza et al., 1998; Zhang et al., 1998; Lin et al., 2010) or collagen II (Persson et al., 1994), cancer pain produced by intramedullary injection of sarcoma cells in the femur of mice (Honore et al., 2000), and excitotoxic injury of spinal cord by intraspinal injection of quisqualic acid (Abraham et al., 2001). Several studies to-date have also reported increased tissue levels of dynorphin, just above, at and below the level of SCI relative to intact controls during the acute/sub-acute phase post-lesion (Faden et al., 1985; Przewlocki et al., 1988; Sharma et al., 1992; Tachibana et al., 1998; Abraham et al., 2001). Moreover, neuropathic pain 
lasting 70 days was induced with a single intrathecal injection of dynorphin in spinally intact animals, suggesting that high tissue levels of dynorphin can result in long-lasting post-injury changes (Vanderah et al., 1996; Laughlin et al., 1997). In addition, the pronociceptive role of increased dynorphin levels in spinal tissues in post-SNL pathophysiology is confirmed when paw withdrawal latencies and response thresholds in prodynorphin (PRDN) gene knockout mice return to normal by day 10 (1) after L5/6 SNL, which coincides with the upregulation of PRDN, and (2) after the intrathecal application of dynorphin antiserum also in a late phase in wild type mice with SNL (Wang et al., 2001). In a study using an inflammatory pain model induced by CFA injection, intrathecal administration of $\mathrm{MK}-801$, a non-competitive blocker of $N$-methyl-D-aspartate receptors (NMDAR) suppressed the upregulation of PRDN mRNA as well as the hyperalgesic response (Zhang et al., 1998) supporting the argument that dynorphin upregulation is needed for induction of the hyperalgesic response.

Accordingly, we hypothesize that (a) an increase in the expression of spinal cord PRDN will also be present during the chronic phase of the current SCI (T8) model of at level (T5-T8) allodynia in male rats and (b) this increased expression of PRDN will be reversed in male rats which receive systemic EB treatment (slow release pellets at serum levels that simulate proestrus) prior to injury. Hence, the effect of the injury and the EB treatment on PRDN levels 6 weeks following a contusion at T8 spinal cord was investigated first by Western blot using the T5-T6 at level spinal tissue and subsequently with immunohistochemistry using the T7 at level spinal tissue. To determine the levels of extracellular dynorphin in spinal tissues, the phosphorylation of $\kappa$-opioid receptor (KOR) at serine 369 was measured. Phosphorylation has been shown to occur in response to prolonged activation by dynorphin, in a concentration dependent manner in the presence of exogenous $\kappa$-specific agonist, U50,488 (Appleyard et al., 1997; McLaughlin et al., 2003). To gain additional insights into potential mechanisms involved, the phenotypes and connectivity of dynorphin-containing neurons were examined using immunohistochemistry, including PRDN expression in neuronal soma and nerve terminals in laminae I and II, which contain important nociceptive circuits (Todd, 2002).

\section{MATERIALS AND METHODS}

Twenty male Wistar rats (four surgical shams, eight placebotreated SCI, and eight EB-treated SCI) approximately 60-70 days old and weighing 200-250 g, were housed individually on a 12-h light-dark cycle and handled daily. One additional non-injured male rat was used for obtaining spinal cord tissues for electron microscopy. All animal procedures were reviewed and approved by the Institutional Animal Use and Care Committee at the University of Louisville, School of Medicine.

\section{EB TREATMENT}

One week prior to SCI (to mirror the procedures in our preceding behavioral study - Hubscher et al., 2010), hormone and placebo pellet insertion was done via a small incision in the skin of the neck just behind the right ear under brief isofluorane anesthesia. Sixteen animals were given subcutaneous implants of either
EB (60-day release, $0.25 \mathrm{mg} /$ pellet; IRA, Sarasota, FL, USA; eight rats) or placebo (eight rats) pellets as previously described (Reed et al., 2009). All experimenters were blinded to the content of the implant. In four sham animals, which did not receive any implants, laminectomy was done without any contusion to the spinal cord. The EB pellets are expected to yield continuous serum hormone levels that are reached during proestrus (Kalra and Kalra, 1974; Nequin et al., 1979; Samuel et al., 1998; Dantas et al., 2002). Furthermore, a previous study from this laboratory showed that the use of these subcutaneous placebo and EB implants in ovariectomized female rats had resulted in the presence of cells in the vaginal smears that resembled the diestrus and proestrus stages, respectively (Reed et al., 2009).

\section{CONTUSION INJURY}

Spinal cord contusions were carried out using a protocol described previously (Hall et al., 2010). Briefly, rats were anesthetized with a mixture of ketamine $(80 \mathrm{mg} / \mathrm{kg}$ of body weight $)$ and xylazine (10 mg/kg of body weight) injected intraperitoneally. The Infinite Horizon Impactor device (Precision Systems and Instrumentation, LLC, Fairfax, VA, USA; Scheff et al., 2003) was used to produce a severe injury at T8 spinal cord exposed after T7 laminectomy, with a pre-set force of $225 \mathrm{kdyn}$ and a 1 -s dwell time. During the postoperative period, all animals were monitored three times daily and were given an analgesic (Ketoprofen, $2.5 \mathrm{mg} / \mathrm{kg}$, sc, twice daily) for 2 days, and Gentamicin ( $5 \mathrm{mg} / \mathrm{kg}$, sc) for 4 days to prevent bladder infections.

\section{BEHAVIORAL MEASUREMENTS}

Behavioral testing of all rats for sensitivity to normally innocuous stimuli (light touch and gentle squeeze/pressure) to monitor allodynia was done in a dedicated facility as previously described (Hall et al., 2010). Baseline measurements were obtained pre-injury for comparison with those obtained during the 6-week post-SCI period. For each testing session, a total of 10 stimuli were applied to the dorsolateral trunk at and just above the level of lesion (T5-T8) alternating between the right and left sides (five each). After each stroking with a number 5 paintbrush (a $17 \mathrm{~g}$ stimulus force), the presence or absence of any one of three types of pain-like behavior (freeze, escape, or grab/push probe with their forepaws) was documented (Hubscher and Johnson, 2006; Hubscher et al., 2008; Hall et al., 2010). Note that for an animal to be considered responsive to a stimulus, the animal has to show a pain-like response during at least $60 \%$ of the trials in a given session (Hubscher and Johnson, 2006; Hubscher et al., 2008). For those animals not responsive to the brush stroke, a gentle squeeze/pressure (a 60-g mechanical, normally innocuous stimulus) was tested using Adson tissue forceps applied to T5-T8 dermatomes on the dorsolateral trunk five times each side using the $60 \%$ criteria.

A 10-point scale (Hall et al., 2010) was used for calculating the allodynia score for each session. The criterion for allodynia is a score higher than 0 on 3-5 weeks, two of which must be on consecutive weeks (to ensure that the response was consistent, and not a one-time occurrence). Scores of 1,2, and 3 were assigned respectively for freeze, escape, or grab/push probe responses to gentle squeeze. An additional three points are added if the same response occurred with the brush stroke, a gentler stimulus. Whenever 
responses to brush strokes occurred, we did further testing with Semmes-Weinstein monofilaments. Points were added for lower thresholds thereby accounting for sensitivity differences. A mean allodynia score is then assigned to each SCI rat, based on the values of five scores obtained from the second week (when allodynia first develops) through the sixth week post-SCI.

\section{TISSUE PROCESSING}

After completion of the chronic 6 weeks post-injury period, each animal was euthanized with a lethal dose of urethane $(2.0 \mathrm{~g}$ urethane/kg of body weight). Enough serum was collected for radioimmunoassay of duplicate samples for serum EB levels, which were then coded and sent to the Ligand Assay and Analysis Core Laboratory at the Center for Research in Reproduction at the University of Virginia Health Sciences Center. Spinal cord tissues were removed for Western blot analysis by cutting a block containing two vertebrae (T4/5) and extruding the cord segments (T5/6) by injecting ice-cold saline, which was then immediately frozen in liquid nitrogen and stored at $-80^{\circ} \mathrm{C}$. The remainder of the spinal cord from $\mathrm{T} 7$ to $\mathrm{T} 13$ was removed with intact vertebral column and placed promptly in $4 \%$ paraformaldehyde for $2-4$ days at $4{ }^{\circ} \mathrm{C}$. The spinal cord was dissected out after laminectomy, cut into segments for immunohistochemistry (T7) and the lesion epicenter reconstruction (T8), transferred into $30 \%$ sucrose solution for at least $48 \mathrm{~h}$ at $4^{\circ} \mathrm{C}$ for cryoprotection, sectioned at $30 \mu \mathrm{m}$ thickness on a cryostat, mounted on positively charged slides (Fisher Scientific, Pittsburgh, PA, USA) and stored at $-20^{\circ} \mathrm{C}$.

For calculating white and gray matter sparing, the slides containing sections from the epicenter (T8) were stained using the Klüver-Barrera method to separately visualize white and gray matter as previously described (Hall et al., 2010). The areas of white and gray matter were estimated using Spot Imaging software (Spot Imaging Solutions, Sterling Heights, MI, USA). The percent sparing was calculated by dividing the total areas of gray and white matters at the epicenter by the total areas of relatively normal gray and white matters at $1 \mathrm{~mm}$ rostral to the epicenter.

\section{WESTERN BLOT}

A modification of previously described protocol was used (Dogra et al., 2006). Each spinal cord segment (T5-T6) from sham and chronic lesioned rats with and without EB treatment, representing 20 animals, was suspended ( $1 \mathrm{mg}$ weight per $20 \mu \mathrm{l}$ ) into ice-cold lysis buffer (50 mM Tris-Cl (pH 7.4), $200 \mathrm{mM} \mathrm{NaCl,} \mathrm{0.3 \%} \mathrm{NP-40,}$ $2 \mathrm{mg} / \mathrm{ml}$ leupeptin, $2 \mathrm{mg} / \mathrm{ml}$ aprotinin, $1 \mathrm{mM}$ phenylmethylsulfonylfluoride, $0.5 \mathrm{mg} / \mathrm{ml}$ benzamidine, $1 \mathrm{mM}$ dithiothreitol, and $1 \mathrm{mM}$ sodium orthovanadate, $50 \mathrm{mM}$ sodium fluoride, $10 \mathrm{mM} \beta$ glycerophosphate) by mechanical grinding in a glass homogenizer. A clear extract was then obtained for Western blot after centrifugation at $4^{\circ} \mathrm{C}$ at $14,000 \mathrm{RPM}$. The protein concentration of each sample was determined using a Bio-Rad protein assay kit (Bio-Rad Laboratories, Inc., Hercules, CA, USA). Each sample containing $50 \mu \mathrm{g}$ of protein was then loaded and electrophoresed with a $10 \%$ SDS gel with 20 lanes using the Protean ${ }^{\circledR}$ II xi Cell system (BioRad Laboratories, Inc., Hercules, CA, USA). The proteins in gel were transferred to nitrocellulose paper. Only those blots showing uniform transfer were later incubated overnight in primary antibodies at appropriate dilutions (Table 1). Horseradish peroxidase linked secondary antibodies (1:1000), goat anti-rabbit IgG and goat anti-mouse IgG (Cell Signaling Technology, Beverly, MA,

Table 1 | List of primary antibodies.

\begin{tabular}{|c|c|c|c|c|}
\hline Antigen & Immunogen & $\begin{array}{l}\text { Manufacturer, species, } \\
\text { type, catalog number }\end{array}$ & Dilution used & Application \\
\hline$\alpha-E R$ & $\begin{array}{l}\text { KLH conjugated synthetic peptide (last } \\
15 \text { amino acids of rat } \alpha-E R \text { ) }\end{array}$ & Upstate, rabbit antiserum, 06-935 & $1: 1000$ & I.H. \\
\hline Dynorphin & $\begin{array}{l}\text { C-terminus of proenkephalin B of } \\
\text { human origin. }\end{array}$ & $\begin{array}{l}\text { Santa Cruz Biotechnology, Inc., goat } \\
\text { polyclonal, sc- } 46313\end{array}$ & $1: 500$ & W.B. \\
\hline KOR-P & $\begin{array}{l}\text { Synthetic polypeptide around residue } \\
\text { S369 in rat KOR }\end{array}$ & Abcam, rabbit polyclonal, ab63511 & $1: 500$ & W.B./I.H. \\
\hline$\beta$-tubulin & $\mathrm{N}$-terminus of human tubulin & Abcam, rabbit polyclonal, ab18587 & $1: 1000$ & W.B. \\
\hline PRDN & $\begin{array}{l}\text { Synthetic sequence (amino acids } \\
245-258 \text { of rat PRDN) }\end{array}$ & $\begin{array}{l}\text { Neuromics, guinea pig polyclonal, } \\
\text { GP10110 }\end{array}$ & $1: 500$ & I.H. \\
\hline NeuN & Purified cell nuclei from mouse brain & $\begin{array}{l}\text { Millipore, mouse monoclonal, } \\
\text { MAB377 }\end{array}$ & $1: 1000$ & I.H. \\
\hline CGRP & $\begin{array}{l}\text { Full length rat protein conjugated to } \\
\text { thyroglobin }\end{array}$ & Abcam, rabbit polyclonal, ab49873 & $1: 2000$ & I.H. \\
\hline VGLUT1 & $\begin{array}{l}\text { C-terminus } 17 \text { residue synthetic } \\
\text { peptide of rat VGLUT1 }\end{array}$ & $\begin{array}{l}\text { Novus Biologicals, rabbit antiserum, } \\
\text { NB 100-1837 }\end{array}$ & $1: 2000$ & I.H. \\
\hline VGLUT2 & Recombinant protein from rat VGLUT2 & $\begin{array}{l}\text { Millipore, mouse monoclonal, } \\
\text { MAB5504 }\end{array}$ & $1: 500$ & I.H. \\
\hline GAD 67/GAD 65 & $\begin{array}{l}\text { Synthetic peptide (identical in GAD67 } \\
\text { and GAD65) conjugated to KLH }\end{array}$ & Abcam, rabbit polyclonal, ab49832 & $1: 1000$ & I.H. \\
\hline Synapsin I & Full length native protein purified (cow) & Abcam, rabbit polyclonal, ab8 & $1: 1000$ & I.H. \\
\hline MAP-2 & Bovine Microtubule associated protein & Sigma, mouse monoclonal, M1406 & $1: 1000$ & I.H. \\
\hline
\end{tabular}


USA), and bovine anti-goat IgG (Santa Cruz Biotechnology, Inc., Santa Cruz, CA, USA) were used.

After incubation with secondary antibodies and washes with phosphate buffered saline (PBS, $\mathrm{pH} 7.4 ; 10 \times$ PBS contained 1.37 M NaCl, $14.7 \mathrm{mM} \mathrm{KH}_{2} \mathrm{PO}_{4}, 78.1 \mathrm{mM} \mathrm{Na}_{2} \mathrm{HPO}_{4}$, and $2 \mathrm{~g}$ $\mathrm{KCl}$ ), the membranes were treated with chemilumiscent horseradish peroxidase detection reagent $\left(\mathrm{HyGLO}^{\mathrm{TM}}\right.$; Denville Scientific, Inc., Metuchen, NJ, USA) and exposed to autoradiography film (Denville Scientific, Inc., Metuchen, NJ, USA). After every Western blot with a specific antibody against a specific antigen, the blots were washed with a stripping buffer (0.2 M Glycine, 10\% Tween 20, 0.1\% SDS, $\mathrm{pH} 2.2$ ) to remove bound antibodies, and re-probed with an anti-rabbit $\beta$-tubulin antibody as a control. $\beta$ tubulin bands were seen at $50 \mathrm{kDa}$ as expected. ImageJ 1.40 (ver. $1.40, \mathrm{NIH}$ ) was used to quantify proteins in the Western Blot. The protein levels were expressed as the total optical density (OD) units in a band, which were normalized by dividing with the total OD units in the corresponding $\beta$-tubulin bands.

\section{IMMUNOHISTOCHEMISTRY}

For immunohistochemistry, sufficient T7 at level tissues (based upon close proximity to T8 contusion) were available from four sham, five SCI animals with placebo treatment and four SCI rats with EB treatment. The experimenter was blinded to the type of implant. A modification of our previously published protocol was used (Cothron et al., 2008). Each slide contained five $30 \mu \mathrm{m}$ sections, which were at least $120 \mu \mathrm{m}$ apart. All slides were heated at $80^{\circ} \mathrm{C}$ in $10 \mathrm{mM}$ sodium citrate buffer for $35 \mathrm{~min}$ for antigen retrieval (Jiao et al., 1999) before each immunohistochemistry. After cooling, slides were washed with $0.1 \mathrm{M}$ Tris buffered saline (TBS containing $150 \mathrm{mM} \mathrm{NaCl}, 50 \mathrm{mM}$ Tris, $\mathrm{pH}$ 7.4) three times, for $5 \mathrm{~min}$ and warmed on a slide warmer for $60 \mathrm{~min}$ at $37^{\circ} \mathrm{C}$. To block the non-specific antigenic sites, slides were incubated for $2 \mathrm{~h}$ in $0.1 \mathrm{M}$ TBS with $5 \%$ donkey and $5 \%$ goat sera. For double labeling studies, sections were incubated in a mixture of two primary antibodies (Table 1) from different species at $4^{\circ} \mathrm{C}$ for $48 \mathrm{~h}$, and washed with $0.1 \mathrm{M}$ TBS with detergent $(0.25 \%$ Triton- $x$, TBS$\mathrm{T})$ for $30 \mathrm{~min}$, six times. Slides were then incubated in a mixture of secondary antibodies for $2 \mathrm{~h}$ at room temperature followed by six washes for $30 \mathrm{~min}$ with TBS-T. Finally, the slides were coverslipped with Fluoromount G (SouthernBiotech, Birmingham, AL, USA), and stored in the dark at $4^{\circ} \mathrm{C}$.

Twenty $1 \mu \mathrm{m}$ thick optical slices of confocal images in $z$ axis were collected with a Nikon Eclipse ${ }^{\circledR}$ microscope, which were rendered to produce a final XY image. Cells and puncta were counted using $\mathrm{NIH}$ software ImageJ which was upgraded with a plugin (Cell Counter) downloaded from $\mathrm{NIH}$ (http://rsbweb.nih.gov/ij/plugins/). For the purpose of counting, a single optical section having $1 \mu \mathrm{m}$ thickness from each Z-stack was used to avoid confusion between co-localization and overlap of structures. Each image was digitally magnified for a clear visualization before counting by increasing the pixel sizes of $X$ and $Y$ dimensions by 7 - to 10 -fold with Adobe Photoshop ${ }^{\circledR}$. Up to three sections were used to generate a mean count from each animal. Each section on a given slide was at least $120 \mu \mathrm{m}$ apart from the others to avoid double counting the same structures. Counting was done separately in two regions, superficial laminae (I and
II) and the remaining laminae (III-X) using boundaries as illustrated in Paxinos' Rat Brain Atlas (Paxinos and Watson, 1998). The settings for exposure, brightness and contrast were adjusted before each image acquisition to get a crisp and clear boundary of histological structures. Negative controls in all studies consisted of replacing the antiserum with the non-immune serum of the host animals. In addition, PRDN antiserum, after blocking in the presence of $1 \mu \mathrm{g} / \mathrm{ml}$ of blocking dynorphin peptide (Neuromics, Edina, MN, USA, Cat\# P10116) in final diluted antibody, was used as an additional negative control for testing the specificity of PRDN antibody. There was an absence of specific staining in all negative controls. To prevent the non-specific labeling, the final concentrations of all antibodies were maintained between 0.5 and $5 \mu \mathrm{g} / \mathrm{ml}$. The secondary antibodies used were DyLight 488, 594 conjugated $\mathrm{F}\left(\mathrm{ab}^{\prime}\right) 2$ fragments of goat or donkey antibodies against IgG of different species (Jackson ImmunoResearch, Inc.). F( $\left.\mathrm{ab}^{\prime}\right) 2$ fragments was used in place of whole antibodies containing Fc portions, which bind in a non-specific manner to the Fc receptors expressed by the macrophages (Diamond and Yelton, 1981) that commonly migrate to the injury sites. The use of better performance flurochromes, DyLight 488 and Dylight 594, was adopted to minimize the photobleaching.

\section{ELECTRON MICROSCOPY}

A single male rat with intact spinal cord was perfused transcardially with $100 \mathrm{ml}$ of $4 \%$ formaldehyde and $0.25 \%$ glutaraldehyde in phosphate buffer under urethane anesthesia. After perfusion, the spinal cord (T6-T7) was immediately removed and post-fixed overnight in $4 \%$ formaldehyde, $0.25 \%$ glutaraldehyde at $4^{\circ} \mathrm{C}$. For nickel-enhanced 3,3'diaminobenzidine (Ni-DAB) immunohistochemistry, $50 \mu \mathrm{m}$ sections were pre-incubated in $10 \%$ normal goat serum for $30 \mathrm{~min}$. Sections were then incubated overnight with antibodies against PRDN or VGLUT2 (Table 1) contained in $5 \%$ normal goat serum. The next day after three, $10 \mathrm{~min}$ washes in PBS, the sections were incubated in appropriate biotinylated secondary antibodies $(200 \times$ dilution). Following $1 \mathrm{~h}$ of incubation, sections were washed again three times for $10 \mathrm{~min}$ in PBS, and later incubated in $\mathrm{ABC}$ solution (Elite Standard $\mathrm{ABC}$ kit, Vector Laboratories, Burlingame, CA, USA). The sections were then washed once in $0.1 \mathrm{M}$ sodium acetate $(\mathrm{pH} \mathrm{6.0)}$ and twice with PBS for $10 \mathrm{~min}$ each. Equal volumes of $0.1 \%$ DAB and $3 \%$ nickel ammonium sulfate in $0.1 \mathrm{M}$ sodium acetate were mixed and $3 \mu \mathrm{l} / 10 \mathrm{ml}$ of hydrogen peroxide was added. Sections were immersed in Nickel/DAB solution containing hydrogen peroxide for $5 \mathrm{~min}$ and then washed once with $0.1 \mathrm{M}$ sodium acetate $(\mathrm{pH}$ 6.0) and twice with PBS for 10 min each. The sections were then stored in PBS at $4^{\circ} \mathrm{C}$ before embedding them in LX112 epon resin for electron microscopy. Ultrathin histological sections ( $800 \AA$ ) were cut and stained with uranyl acetate. Stained sections were mounted on a 200 mesh copper grid and viewed under Philips CM-12 transmission electron microscope with an operating voltage of $80 \mathrm{kV}$. Electron micrographs were obtained under 10,000× to $19,500 \times$ magnifications.

\section{STATISTICAL ANALYSIS}

A two-way ANOVA followed by Tukey HSD post hoc pairwise $t$ tests using SPSS software (SPSS Inc., Chicago, IL, USA) was used to 
analyze the effect of the injury and the EB treatment on the expression levels of various proteins obtained by the Western blot study. The confocal data was analyzed by the GraphPad Prism $5.0(\mathrm{La}$ Jolla, CA, USA). Pearson Correlation test was done to study different correlations. The value of $p$ for rejection of null hypothesis was set at 0.05 for all analyses.

\section{RESULTS}

\section{SEVERITY OF INJURY}

The actual force of compression of the spinal cord at T8, measured at the tip of the impounder, averaged $227 \pm 3.7 \mathrm{kdyn}$ with an average displacement of $1.2 \pm 0.1 \mathrm{~mm}$ in placebo-treated animals and $225 \pm 2.1 \mathrm{kdyn}$ with an average displacement of $1.4 \pm 0.1 \mathrm{~mm}$ in EB-treated animals. The number of animals used initially in this study including 4 shams was 20; however, 1 animal in the EBtreated group was excluded from the data analysis as the values of initial parameters of injury from Infinite Horizon Impactor did not meet our minimum criteria for the desired injury severity (displacement above $1.0 \mathrm{~mm}$ which is necessary to obtain a "severe" SCI and thus allodynia). The average percent white matter sparing at the lesion epicenter (T8) was $4.2 \pm 1.7$ and $5.5 \pm 0.8 \%$, respectively in placebo $(n=8)$ and EB-treated $(n=7)$ rats. The mean percent gray matter sparing was $0.21 \pm 0.21$ and $0.24 \pm 0.17 \%$ in placebo and EB-treated SCI rats, respectively. The low percent sparing of gray and white matters indicates the presence of severe injuries in these animals, which is expected from an injury force of $225 \mathrm{kdyn}$ with a dwell time of $1 \mathrm{~s}$.

\section{SYSTEMIC EB LEVELS AFTER SUBCUTANEOUS PELLET TREATMENT}

The mean serum EB level in male rats receiving subcutaneous EB pellets ( 7 weeks post-implant; 6 weeks post-SCI) was $50.5 \pm 13.1 \mathrm{pg} / \mathrm{ml}$, which is significantly $(p<0.01)$ higher than the mean level of $9.4 \pm 4.0 \mathrm{pg} / \mathrm{ml}$ observed in the rats that had received subcutaneous pellets containing vehicle alone. The values of EB levels in the treated group were similar to those seen during the proestrus phase in female rats (Nequin et al., 1979; Kramer and Bellinger, 2009; Santmyire et al., 2010).

\section{BENEFICIAL EFFECT OF SYSTEMIC EB TREATMENT ON PAIN-LIKE BEHAVIOR IN SCI RATS}

At level (T5-T8) allodynia developed in seven out of eight male animals in the placebo-treated group. The high incidence of allodynia in adult male rats with a severe T8 contusion in the placebotreated group is consistent with our previous studies (Hubscher and Johnson, 1999, 2006; Hall et al., 2010; Hubscher et al., 2010). In contrast, only three from the group of seven EB-treated male animals (with proestrus-like EB levels for proof of principle) showed allodynia. A binomial proportion test corrected for small sample sizes (Siegel and Castellano, 1988) showed significant differences between the incidence of allodynia in the two groups $(p<0.01)$.

\section{THE WESTERN BLOT STUDY OF PRDN AND KOR-P EXPRESSION AT LEVEL}

A two-way ANOVA revealed significant main effects of injury $[F(1,16)=16.35, p=0.001]$ and the $\mathrm{EB}$ treatment on the spinal cord (T5-T6) levels of PRDN $[F(1,16)=12.53, p<0.005$; Figure 1A]. Tukey HSD post hoc test further revealed that injury significantly increased tissue levels of PRDN, which was significantly reduced by EB pretreatment ( $p<0.01$, both).

A significant main effect of injury on tissue levels of KOR$\mathrm{P}$ in the spinal cord $[F(1,16)=8.73, p<0.01]$ was also seen (Figure 1B). However, a main effect of EB treatment on KOR-P levels was not detectable, which may be attributed to the relatively small sample size of the sham group of animals. Significantly, higher spinal cord (T5-T6) levels of KOR-P were observed in SCI rats with placebo treatment in comparison to the sham animals $(p<0.01)$. The Pearson correlation analysis revealed a significant positive correlation between the tissue levels of KOR-P and PRDN $(p=0.001, r=0.72$, Figure 1C), indicating that the changes in KOR-P levels are paralleled by changes in PRDN levels in the spinal cord tissues after the SCI.

THE IMMUNOHISTOCHEMICAL STUDY OF PRDN EXPRESSION AT LEVEL Figure 2 shows PRDN expression at T7 (the typical example shown is from SCI rats with placebo treatment). The magnified image (Figure 2C) of the superficial laminae shows co-expression of PRDN in NeuN labeled neurons. Note the puncta-like profile of PRDN expression (Figure 2C), which is consistent with its expression within nerve terminals, dendrites, and axons. No significant co-expression with dendritic marker microtubule associated protein-2 was seen (data not shown). However, PRDN co-expression with the nerve terminal marker synapsin I (De Camilli et al., 1983) was seen (Figure 2E). In total, 887 (mean: $177 \pm 17$ per $1 \mu \mathrm{m}$ thick optical section) out of 1421 (mean: $285 \pm 49$ per section) PRDN-IR puncta $(\sim 62 \%)$ in all laminae ( $n=5$; one section counted per placebo-treated SCI animal) showed co-expression with synapsin I.

To study the phenotype of dynorphin terminals, double labeling was done with antibodies against vesicular glutamate transporter1 (VGLUT1) and vesicular glutamate transporter2 (VGLUT2), which are markers for glutamatergic terminals (Fremeau et al., 2004), and glutamate decarboxylase 67/glutamate decaboxylase 65 (GAD67/GAD65), which is the marker for the inhibitory GABAergic terminals (McLaughlin et al., 1975). Only VGLUT2 and PRDN co-expression was seen (Figure 2F). A total of 467 (mean: $93 \pm 8$ per section) PRDN-/VGLUT2-double labeled puncta were present among 1263 (mean: $253 \pm 18$ per section) PRDN-IR puncta, $(\sim 37 \%)$, which is based on counts from all laminae ( $n=5$; one section per animal). When considered in combination with our finding that $\sim 62 \%$ of PRDN-IR puncta co-label synapsin I, it is estimated that $\sim 60 \%$ (37 of $62 \%$ ) of dynorphin terminals at level are glutamatergic. Since dynorphin expression in spinal cord is mostly within the interneurons, which is indicated by previous studies showing the lack of effect of bilateral dorsal rhizotomy (Botticelli et al., 1981) or complete mid-thoracic transection (Goldstein and Ghazarossian, 1980) on the dynorphin contents of the spinal cord, it is contended that VGLUT2/PRDNIR puncta in spinal cord most likely represent the terminals from interneurons.

The lack of PRDN co-expression with GAD67/GAD65 (data not shown) indicates the absence of a significant number of inhibitory dynorphin terminals. A significant number of GAD67/GAD65-IR puncta were however found to be juxtaposed to PRDN-IR cell bodies and puncta, consistent with inhibitory 


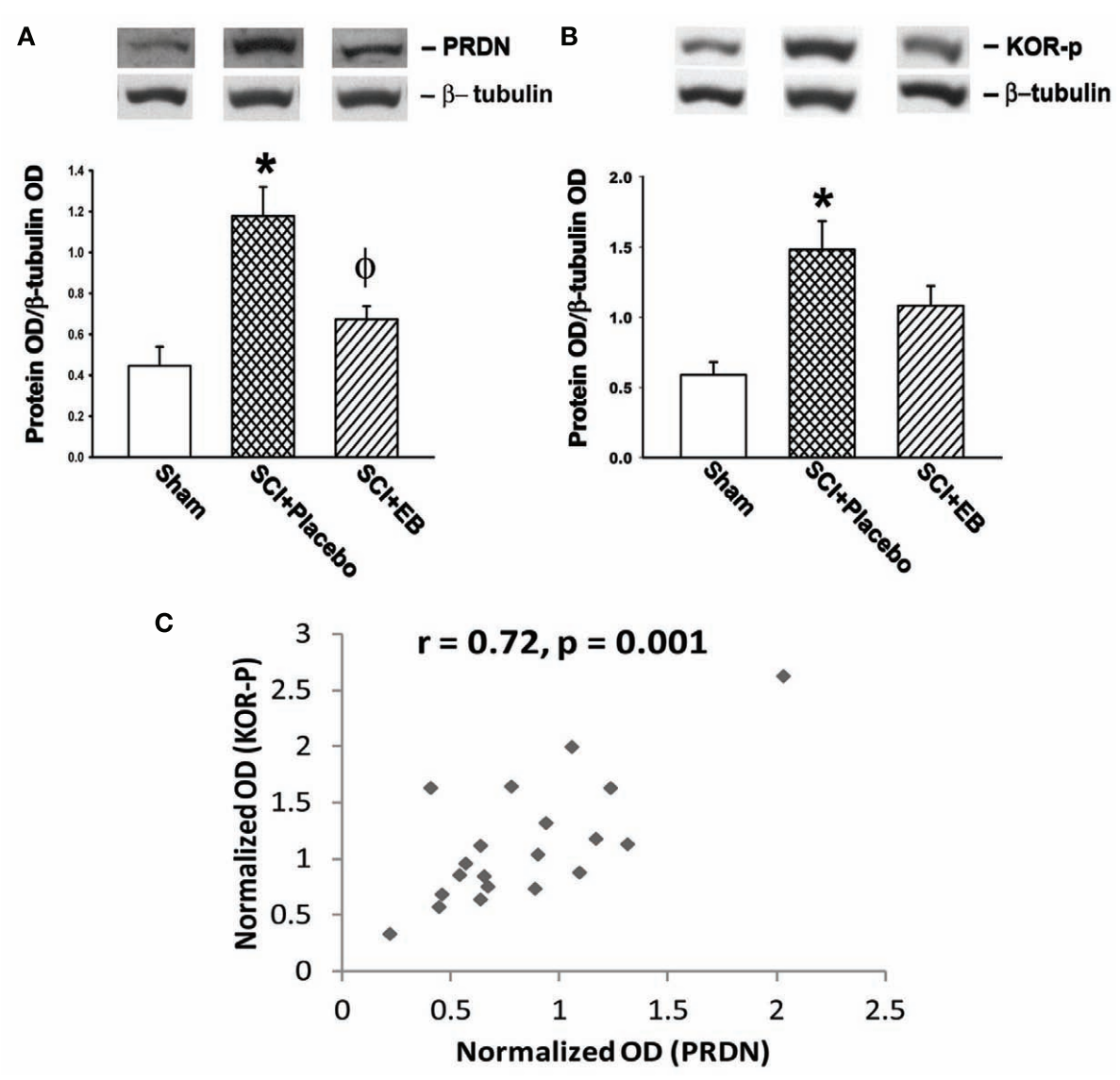

FIGURE 1 | (A,B) Western blot analysis of at level (T5-T6) spinal cord 6 weeks following spinal cord injury (SCI) in male rats shows prodynorphin (PRDN) band at $\sim 26 \mathrm{kDa}$ and the phospho-(serine 369)-k-opioid receptor (KOR-P) band at $\sim 43 \mathrm{kDa}$. (A) The tissue levels represented by PRDN band shows a significant elevation ( $164 \%$ ) post-SCl in rats with placebo treatment $\left({ }^{*} p<0.01\right)$. The increased PRDN levels in $\mathrm{SCl}$ rats was significantly reversed in the group of male rats having proestrus-like serum levels of $17 \beta$ estradiol (EB; $\Phi, p<0.01$ ). (B) Spinal cord level of KOR-P was significantly elevated $(\sim 151 \%)$ in the placebo-treated $\mathrm{SCl}$ animals in comparison to the shams $\left({ }^{*} p<0.01\right)$. The KOR-P levels after EB treatment were not found to be significantly different from those in either the sham or the placebo-treated group. (C) Depicts the presence of a positive correlation between the normalized OD (optical density) units representing the tissue levels of PRDN and KOR-P in the at level spinal cord. The total OD units of PRDN and KOR-P bands were normalized after division with the respective OD levels of $\beta$-tubulin ( $50 \mathrm{kDa}$ band). All data are represented as mean $\pm \mathrm{SEM}$ of the normalized OD values, and were analyzed by ANOVA. $n=4$, Sham; $n=8$, $\mathrm{SCl}+$ placebo; $n=7, \mathrm{SCl}+\mathrm{EB}$. inputs to dynorphin neurons. A similar conclusion was reached previously based on an ultrastructural analysis (Cho and Basbaum, 1989).

Double labeling with antibodies for different estrogen receptors (ERs), ER $\alpha, E R \beta$, and G-protein coupled estrogen receptor-1 (GPER-1)/G-protein coupled receptor 30 (GPR30) antibodies in T7 spinal tissues revealed only PRDN/ER $\alpha$ co-expression, which was seen predominantly in laminae I and II (Figure 2D; data is not shown for other antibodies). PRDN/ER $\alpha$ co-expression was shown previously in the intact lumbar and sacral spinal cord segments of female rats (Gintzler et al., 2008). The co-expression of PRDN and $E R \alpha$ provides a morphological basis for the effect of EB treatment on the tissue levels of PRDN in the at level spinal cord.

\section{ELECTRON MICROSCOPIC STUDY OF PRDN-, VGLUT2-IR EXPRESSION}

The electron microscopic images confirm PRDN labeling of vesicles in the nerve terminals, endoplasmic reticulum, and myelinated axons (Figures 3A-D). The expression within nerve terminals and axons is consistent with the puncta- and fiber-like profiles seen in the confocal images (Figure 2C). In a magnified view of a synaptic nerve terminal labeled by PRDN (Figure 3D), the synaptic cleft is seen filled with DAB-Ni precipitate (white arrowheads), which may represent diffusion of dynorphin after its release. The presence of post-synaptic density is consistent with the excitatory phenotype of dynorphin nerve terminals. Notably, PRDN labeling is absent from the dendrites, which is consistent with our immunohistochemical analysis. VGLUT2 specific DAB-Ni labeling is seen within dendrites, axons, and vesicles inside the nerve terminals (Figures 3E,F).

PRDN EXPRESSION IN SUPERFICIAL (I-II) VS. DEEPER LAMINAE (III-X) The frequent co-expression of ER $\alpha / P R D N$ in superficial laminae (typical examples in Figure 2) indicates the possibility that EB treatment may affect the dynorphin expression of neurons in laminae I and II, which contains important nociceptive circuits. To study the effect of systemic EB treatment on PRDN expression 
A

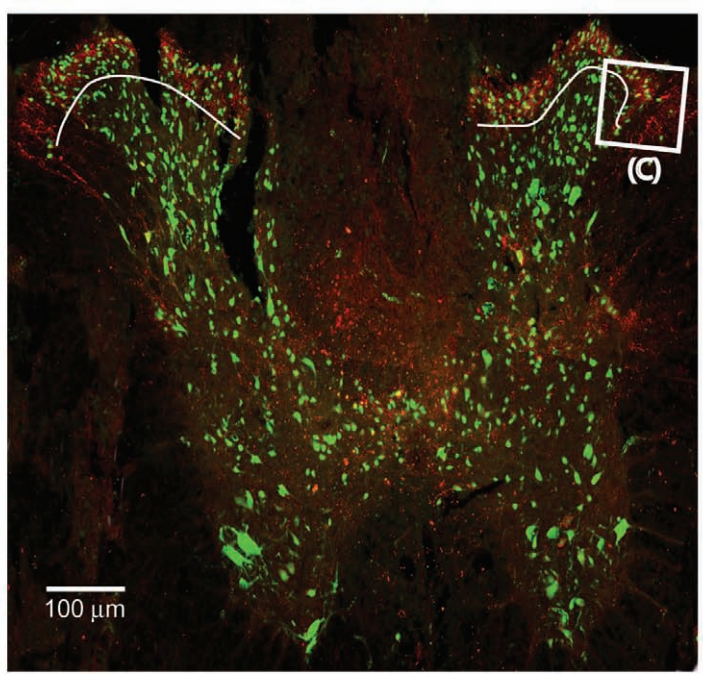

B

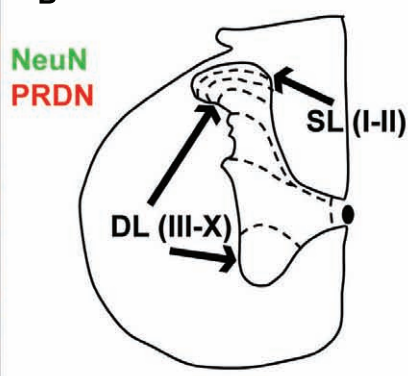

(a)

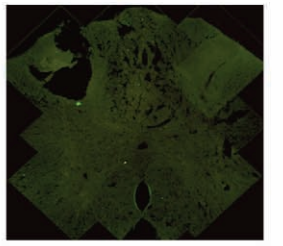

$\alpha-E R$ PRDN
C

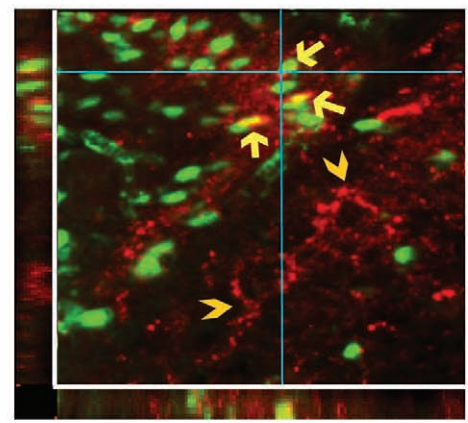

Synapsin-I PRDN

E

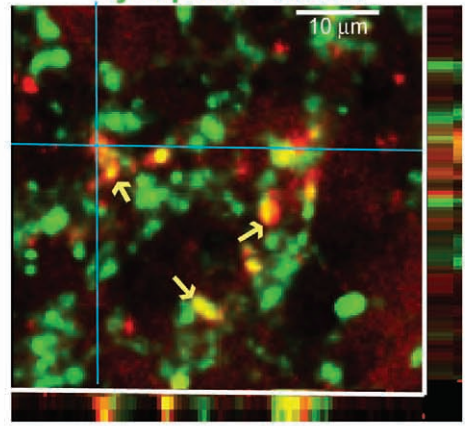

S.L.

D

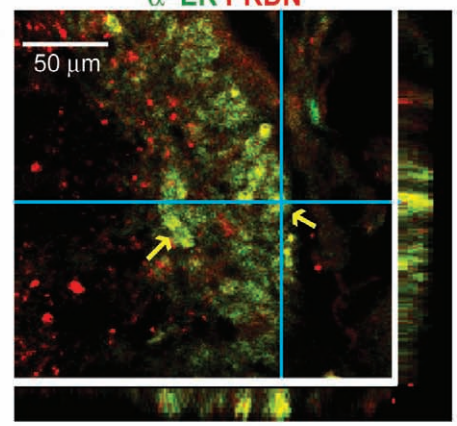

D.L.

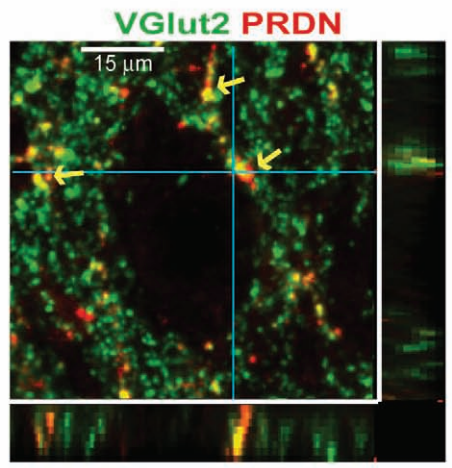

(yellow arrowheads) suggestive of expression in axons. (D) Shows the co-localization of PRDN and estrogen receptor $\alpha(E R \alpha)$ in SL (yellow arrows). Image (E) shows the co-expression of nerve terminal marker, synapsin I within the PRDN-IR puncta (shown in deep laminae (DL), yellow arrows). (F) PRDN-IR puncta is shown to co-express glutamatergic marker vesicular glutamate transporter 2 (VGLUT2). Image in (a) shows a typical absence of specific labeling in a section at 77 from $\mathrm{SCl}$ animals with placebo, when primary antibodies (PRDN and NeuN) were substituted with non-immune sera from the respective host animals. Images shown are typical of sham, $\mathrm{SCl}+$ placebo and $\mathrm{SCl}+\mathrm{EB}$ rats $(n=4-5$ each). For consistency, only images from the $\mathrm{SCl}+$ placebo group of male rats are shown. Co-localizations [yellow arrows in $(\mathbf{C}, \mathbf{F})$ ] are also seen in $\mathrm{XZ}$ and $\mathrm{YZ}$ planes passing through the blue lines. Abbreviations are as in Figure 1. within neurons in laminae I and II, counts of PRDN-/NeuN-IR neurons were compared between the superficial laminae (laminae
I-II) and the rest of the gray matter (laminae III-X; Figure 4A). A two-way ANOVA revealed significant main effects of the region 
A

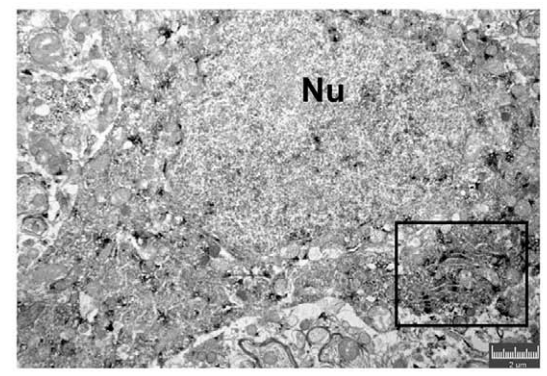

C

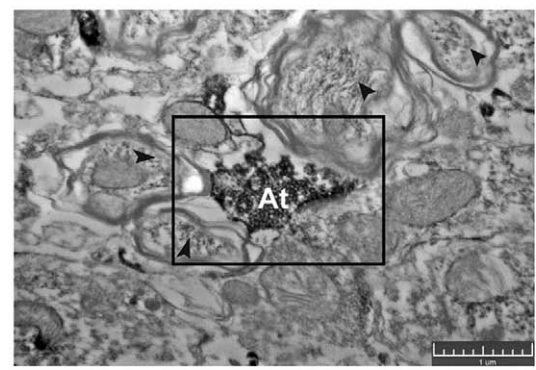

E

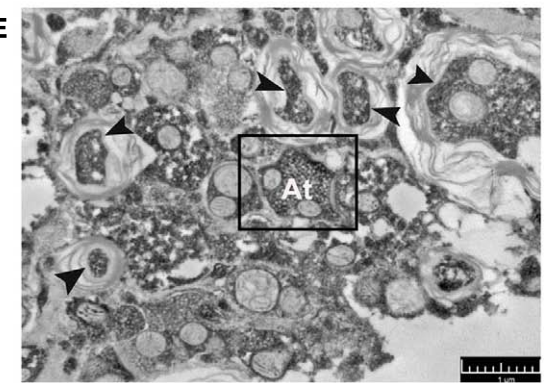

FIGURE 3 | Representative electron microscopic images of T7 spinal cord sections from an uninjured animal illustrate immunocytochemical staining of PRDN (A-D) and VGLUT2 (E,F) visualized with the nickel-enhanced diaminobenzidine (DAB-Ni) reaction. Images in (B,D,F) illustrate at higher magnification the boxed portions indicated in $(\mathbf{A}, \mathbf{C}, \mathbf{E})$, respectively. PRDN labeling is seen in the cytoplasm of neurons [( $\mathbf{A})$ nucleus indicated, Nu] where DAB-Ni is associated with endoplasmic reticulum [white arrowheads (B)]. PRDN is also seen in axon terminals (At) where DAB-N surrounds synaptic vesicles [white arrows (D)]. PRDN-labeled terminals
B

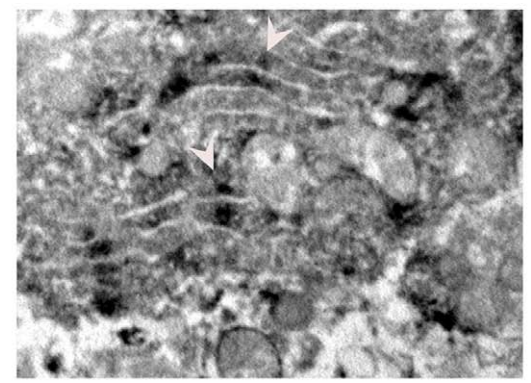

D

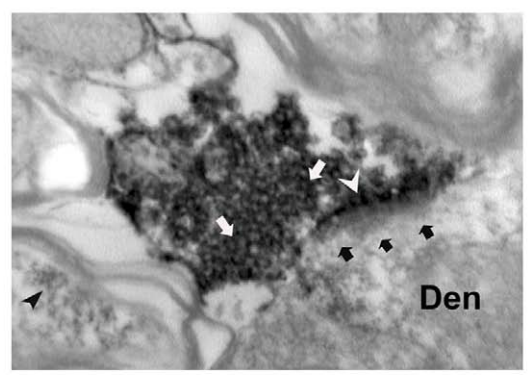

$\mathbf{F}$

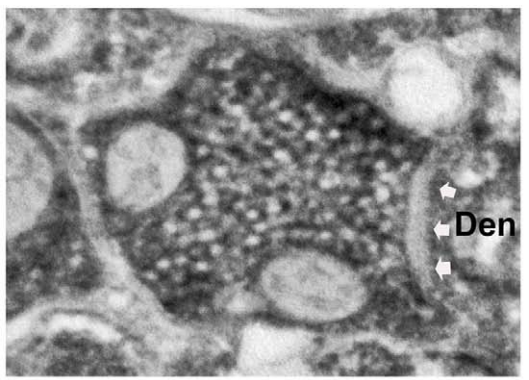

contact the unlabeled dendrites [Den, black arrows point to the post-synaptic density, white arrowhead indicates synaptic cleft filled with more intense, DAB reaction from released dynorphin (D)]. (D) PRDN-IR rounded vesicles (white arrows) are seen. Light PRDN labeling of myelinated axons is also seen [black arrowheads (C,D)]. (E,F) VGLUT2 labeling is seen in myelinated axons (black arrowheads), axon terminals (At), and dendrites (Den). (F) VGLUT2 labeled terminals contact VGLUT2 labeled dendrites (black arrows indicate the synaptic cleft). The scale bars measure $2 \mu \mathrm{m}$ in (A) and $1 \mu \mathrm{m}$ in (C,E). Abbreviations are as in Figures $\mathbf{1}$ and $\mathbf{2}$.

[laminae I and II vs. the rest of the gray matter, laminae IIIX; $F(1,14)=29.7, p<0.01$ ] and the treatment groups [placebo vs. EB pellets; $F(1,14)=6.56, p<0.03$ ]. There was a significantly higher number of PRDN-/NeuN-IR neurons in laminae I to II in comparison to the rest of the gray matter (laminae III-X) in both groups of SCI rats ( $p<0.05$ for both comparisons; 4.5 times higher in laminae I and II in the placebo group). Comparisons of specific groups using $t$-tests showed a significant drop in the number of PRDN-/NeuN-IR neurons by $48 \%$ in laminae I to II in SCI rats after EB treatment $(p<0.05)$. Note that we did not include the sham animals in this analysis because the neuronal cell loss, which affects the two SCI groups (those with placebo and EB, but not the sham group), could confound the analysis. Moreover, based on Western blot expression, an increase in the counts of PRDN positive NeuN neurons and/or immunoreactivity intensity was anticipated after the injury in the placebo treatment group. A two tailed $t$-test, with the assumption of equal variance, showed an absence of any significant differences in counts observed in the sham group (31/section) vs. the SCI placebo treatment group (27/section; $p>0.05)$.

The effect of EB treatment on dynorphin expression in nerve terminals was examined by analyzing counts of synapsin I-/PRDNIR puncta (Figure 4B). The two-way ANOVA revealed significant main effects of the region $[F(1,14)=11.3, p<0.01]$ and the treatment group $[F(1,14)=23.5, p<0.01]$ on the counts of synapsin I-/PRDN-IR puncta. Further post hoc comparisons showed significantly lower counts of synapsin I-/PRDN-IR puncta in laminae I-II $(p<0.05)$ and laminae III-X $(p<0.01)$ in animals with the subcutaneous EB pellets vs. the placebo pellets. Decreased counts of synapsin I-/PRDN-IR puncta following EB treatment is 
A

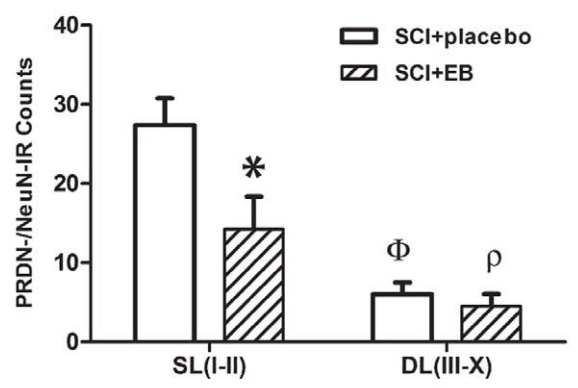

FIGURE 4 | (A) In the superficial laminae I-II (SLI-II), significantly higher counts ( $y$-axis) of PRDN-/NeuN double labeled neuronal soma are present in the placebo-treated vs. the EB-treated $\mathrm{SCl}$ animals $\left({ }^{*} p<0.05\right)$. The number of PRDN-/NeuN double labeled cells is significantly more in SLI-II as compared to the deeper laminae, III-X (DLIII-X) in placebo $(\phi, p<0.01)$ and EB-treated $(\rho, p<0.01)$ groups of $\mathrm{SCl}$ animals. (B) Significantly higher counts of synapsin I-/PRDN-IR puncta-like profile, representing dynorphin nerve terminals, are present in the placebo-treated $\mathrm{SCl}$ group as compared
B

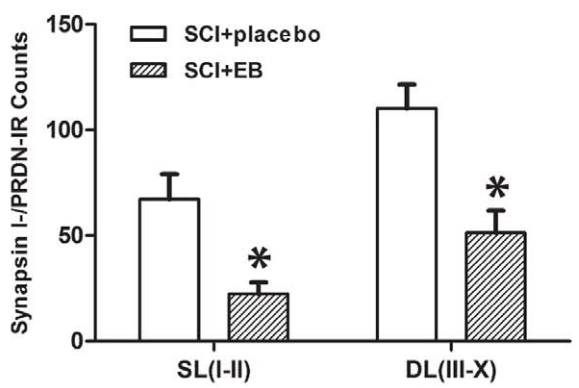

to the EB-treated SCI group in both regions, the SLI-II and DLIII-X ${ }^{*} p<0.05$, for both). Before counting, the gray matter was divided into SL I-II and DL III-X based on the "The Rat Brain in Stereotaxic Co-ordinates" by Paxinos and Watson (1998), as shown in the schematic in Figure 2B. A complete optical section $(1 \mu \mathrm{m})$ taken from the center of stacks of confocal images was counted. Counts shown on the $x$-axis are mean \pm SEM per section ( $n=4-5)$, and was analyzed by a two-way ANOVA. Abbreviations are as in the Figure $\mathbf{1}$. consistent with reduced dynorphin content in the nerve terminals indicating a potential reduction in the dynorphin release.

\section{DISCUSSION}

The current study reveals a beneficial outcome following subcutaneous treatment with EB that resulted in significantly lowered incidence of pain-like behavior that was detected in male rats after a chronic SCI. Various favorable outcomes have been also reported for systemic EB treatment in other studies (Yune et al., 2004; Webb et al., 2006; Hubscher et al., 2010; Kachadroka et al., 2010). Our study suggests that beneficial outcomes may result, at least partly, by preventing the post-injury toxicity resulting from increased dynorphin expression in spinal cord. Several types of evidence presented in the current study indicate reduced dynorphin expression after treatment with subcutaneous EB pellets. These include reduced tissue levels of PRDN, reduced count of PRDN-labeled NeuN positive neurons, a positive correlation between the tissue levels of PRDN and KOR-P and reduced PRDN labeling of synapsin I-IR puncta, which represent nerve terminals. In addition, others have shown previously that subcutaneous EB replacement can reduce the expression of PRDN in the central nervous system. For example, EB replacement suppressed the post-ovariectomy increase in PRDN gene expression in the adenohypophysis in rats (Spampinato et al., 1995). EB replacement mechanism in ovariectomized mice also reduced the PRDN expression in the arcuate nucleus by an ER $\alpha$ mediated (Gottsch et al., 2009).

Note that the present study was limited to male rats since males constitute $80.7 \%$ of the total SCI population (National Spinal Cord Injury Statistical Center, Birmingham, AL, USA - February 2011). However, the current use of estrogens for therapeutic purposes in males is limited because of the serious side effects, such as thromboembolism (Sayed and Taxel, 2003). There are current clinical trials of promising new therapeutic agents for potential use in males known as selective ER modulators, which mimic the effects of estrogen without their serious side effects (Pickar et al., 2010).
Also note that other indirect effects of systemic EB treatment, such as reduced levels of testosterone as well as luteinizing and follicular stimulating hormone, which are observed during EB infusion (Bagatell et al., 1994), may also contribute to the decreased dynorphin levels and/or its beneficial effects. However, the present data, showing the reduction in the count of PRDN-/NeuN-IR neurons induced by systemic EB treatment in the superficial laminae where $\mathrm{ER} \alpha$ and PRDN co-expression is seen, supports the direct involvement of EB on dynorphin expression.

\section{EXPRESSION OF PRDN AND KOR-P}

The Western blot analysis in this study demonstrates an increase of PRDN levels in the at level (T5, T6) spinal cord tissues of male rats with severe chronic (6 weeks) SCI at T8, which is reversed in animals given subcutaneous EB implants prior to the injury (shown to result in proestrus-like blood levels of EB upon measurement at the terminal stage). An increase in the synthesis of PRDN is expected to increase the extracellular levels of the most abundant form of endogenous $\mathrm{K}$-opioid in the spinal cord, dynorphin A (1-17; Chen et al., 2007), which was studied by measuring the tissue levels of KOR-P, since phosphorylation at serine 369 of $\mathrm{KOR}$ is dose dependent in response to activation by $\mathrm{\kappa}$-agonists (Appleyard et al., 1997; McLaughlin et al., 2003). Our data reveals a significant increase in the KOR-P levels in post-SCI spinal tissues, corresponding to sensitive dermatomes (T5-T8), which is consistent with increased activity of dynorphinergic terminals in spinal cord at level. The tissue KOR-P levels after EB treatment were found not to be significantly different from those after the placebo treatment. In addition, a significant positive correlation between the levels of PRDN and KOR-P in post-SCI spinal cord tissues (Figure 1C) is found, which indicates that the PRDN levels positively influence the levels of KOR-P, an indicator of magnitude of dynorphin release.

The decreased release of dynorphin with continuous EB treatment may be due to the diminished stores in nerve terminals, which are indicated by a significant reduction in detectable PRDN 
labeling of synapsin I-IR nerve terminals (by $\sim 67 \%$, as shown in Figure 4). The reduced PRDN labeling of the nerve terminals is likely to be associated with the decreased expression of PRDN within the neurons in the superficial laminae after EB treatment. In this context, note that the count of PRDN-/NeuN-IR neurons in superficial laminae I and II, showing frequent PRDN/ER $\alpha$ co-expression, declined by $48 \%$ following EB treatment. Another finding worthy of note is the absence of a significant increase in the counts of PRDN positive NeuN neurons after the injury relative to shams. This may be due to the overall loss of neurons following injury. Hence, it is likely that the significantly increased dynorphin levels detected after injury by the Western blot analysis may be due to the increase of its levels in the surviving neurons, axons, and the nerve terminals.

We propose that EB pretreatment, by preventing increased dynorphin expression following SCI, is responsible for the improved behavioral outcome (reduction in the incidence of at level allodynia) previously reported by our group (Hubscher et al., 2010) and observed again with the current group of rats.

\section{PRDN EXPRESSION ENHANCES NEURONAL EXCITABILITY VIA NON-OPIOID MECHANISMS}

The immunohistochemical and electron microscopic data shows that dynorphin is expressed in a subpopulation of glutamatergic (VGLUT2) nerve terminals at T7 (consistent with Marvizon et al., 2009), indicating an excitatory phenotype of dynorphin terminals, which is further supported by the electron microscopic finding of the post-synaptic density (Figure 3D; Guillery, 2000). This finding is important for understanding the non-opioid basis for the adverse effects of dynorphin, resulting from increased tissue levels post-injury. It has been proposed by Laughlin et al. (2001) that the interaction of dynorphin with NMDARs via multiple binding sites can produce excitatory responses resulting in nociceptive behavior and other adverse effects. The non-opioid basis for the toxic effects of dynorphin is supported by experimental evidence employing the intrathecal injection of fragments lacking the opioid activity, such as dynorphin A (2-17) and dynorphin A (3-17), in addition to dynorphin A (1-17) with full opioid activity, all of which produce persistent adverse effects on sensory, motor and autonomic functions leading to allodynia, hind limb locomotor function loss, and bladder function impairment (Long et al., 1988; Vanderah et al., 1996; Laughlin et al., 1997).

Both the NMDAR dependent and NMDAR independent mechanisms are found to be responsible for the effects of dynorphin in pharmacological and in vitro studies (Tang et al., 2000; Laughlin et al., 2001; Woods et al., 2006). NMDAR independent effects of dynorphin include increasing $\mathrm{Ca}^{++}$influx in hybridoma cell lines of embryonic rat dorsal root ganglia cells, mediated by bradykinin receptor $\mathrm{B} 2$, which was also responsible for nociceptive behavior after L5, L6 SNL in rats (Lai et al., 2006). The $\mathrm{Ca}^{++}$influx caused by dynorphin may also lead to increased release of neurotransmitters (Perney et al., 1986) at the dynorphin terminals, which are widely distributed. The activation of $\mathrm{Ca}^{++}$dependent protein kinase $\mathrm{C}$, following the $\mathrm{Ca}^{++}$influx produced by dynorphin, can also cause NMDAR activation (Tang et al., 2000). Consistent with this hypothesis, the low pharmacological doses of dynorphin $\mathrm{A}$ (1-13), which increased the $\mathrm{Ca}^{++}$influx, were shown to contribute to the post-synaptic enhancement of NMDAR (Skilling et al., 1992).

Dynorphin also directly activates NMDARs via binding to the NR1 subunit, which was shown to be responsible for its toxicity in vivo and in vitro (Woods et al., 2006). According to an emerging concept, the activity of NMDARs is essential for synaptogenesis, experience-dependent synaptic remodeling and long-lasting changes in synaptic efficacy such as long-term potentiation and long-term depression (Lau and Zukin, 2007), which is likely to play important role in the post-injury toxicity of dynorphin in spinal tissues, since many of the adverse effects of intrathecal dynorphin are persistent in nature (Long et al., 1988; Vanderah et al., 1996; Laughlin et al., 1997).

Evidence for increased neuronal activity includes a study using c-fos, a marker of neuronal activity in gray matter immediately above the level of injury in a SCI model exhibiting at level allodynia (Siddall et al., 1999). The hypersensitivity of neurons in ventral and posterior thalamic nuclei evoked by stimulation of at level (T5-T8) dermatomes in the current model of SCI (Hubscher and Johnson, 2006) suggests increased stimulation of spinothalamic neurons in the spinal cord. Direct recordings of dorsal horn neurons at cervical (Carlton et al., 2009) and at spinal cord levels immediately rostral (T8/9; Crown et al., 2008) to a contusion injury at T10 also showed increased responses to various mechanical stimuli, indicating an injury-induced increase in neuronal activity. The NMDAR activation is seen in animal models exhibiting upregulation of dynorphin in spinal cord. In S2 and L5/6 SNL models, the intrathecal injection of the non-competitive inhibitor of NMDAR, MK-801 suppressed the increased pain response (Malan et al., 2000; Wang et al., 2001). In the neuropathic pain model induced by intrathecal dynorphin injection, intrathecal injection of MK-801 produced transient blockade of the mechanical allodynia (Laughlin et al., 1997). It is important to note that the acute effects of systemic EB can also reduce activity of NMDARs, which is independent of genomic mechanisms, such as reduced expression of dynorphin, as indicated by rapid and reversible inhibition of NMDAR currents in a hippocampal neuron culture (Weaver et al., 1997), and may contribute to the overall beneficial effect of EB in a chronic injury model.

\section{POSSIBLE ATTENUATION OF OPIOID EFFECT IN MODELS WITH DYNORPHIN UPREGULATION}

An increased inhibitory $\kappa$-opioid tone, responsible for antinociceptive effect, is demonstrated in an arthritic pain model, exhibiting increased levels of dynorphin in the lumbar sacral spinal cord, which showed that hyperalgesia was potentiated by a $\kappa$ specific antagonist, MR2266 (Millan et al., 1985). Note that the current study shows high levels of KOR-P in spinal tissues after severe chronic SCI, which is consistent with the development of desensitization to the effects of KOR activation by dynorphin (McLaughlin et al., 2003). Therefore, we argue that although inhibitory opioid tone may be present as a result of increased tissue levels of dynorphin, promoting anti-nociception as detected in a previous study (Millan et al., 1985), it is likely to undergo significant attenuation as a result of the desensitization. Absence of a significant role of $\kappa$-opioid activity is indicated in a L5/L6 SNL model which did not show difference in the stimulation of 
$\gamma$-[35S]GTP binding by $\kappa$ receptor agonist U69,593 with or without SNL surgery (Wang et al., 2001).

\section{OTHER BENEFITS OF EB TREATMENT}

The maladaptive changes and associated increase in excitability caused by the elevated levels of tissue dynorphin can plausibly contribute to other consequences of SCI, such as locomotor deficits, muscle spasticity, sexual dysfunction, autonomic dysreflexia, and bladder and bowel dysfunction (Levi et al., 1995; WiderstromNoga et al., 1999). Note that the potential benefits of EB treatment on locomotor systems has been studied by several groups within the context of neuroprotection, as already discussed. Our future studies will examine the benefits of EB relative to reducing excessive levels of dynorphin, for locomotor as well as other systems (pelvic visceral function). Also note that over-stimulation of motor neurons can cause spasticity. The development of high excitotoxic levels of extracellular dynorphin may contribute to the motor deficits due to the loss of motor neurons. The increased activity and/or the loss of sympathetic and the parasympathetic neurons in thoracic and lumbosacral segments (Jansen et al., 1993; de Groat, 1998) could contribute to the bladder and/or sexual and/or autonomic dysfunctions following the SCI.

It is noteworthy that the incidence of fibromyalgia, a chronic pain condition associated with elevated levels of dynorphin in cerebrospinal fluid (Vaeroy et al., 1991), increases sharply after

\section{REFERENCES}

Abraham, K. E., McGinty, J. F., and Brewer, K. L. (2001). Spinal and supraspinal changes in opioid mRNA expression are related to the onset of pain behaviors following excitotoxic spinal cord injury. Pain 90, 181-190.

Appleyard, S. M., Patterson, T. A., Jin, W., and Chavkin, C. (1997). Agonistinduced phosphorylation of the kappa-opioid receptor. J. Neurochem. 69, 2405-2412.

Bagatell, C. J., Dahl, K. D., and Bremner, W. J. (1994). The direct pituitary effect of testosterone to inhibit gonadotropin secretion in men is partially mediated by aromatization to estradiol. J. Androl. 15, 15-21.

Botticelli, L. J., Cox, B. M., and Goldstein, A. (1981). Immunoreactive dynorphin in mammalian spinal cord and dorsal root ganglia. Proc. Natl. Acad. Sci. U.S.A. 78, 7783-7786.

Calza, L., Pozza, M., Zanni, M., Manzini, C. U., Manzini, E., and Hokfelt, T. (1998). Peptide plasticity in primary sensory neurons and spinal cord during adjuvant-induced arthritis in the rat: an immunocytochemical and in situ hybridization study. Neuroscience 82, 575-589.

Carlton, S. M., Du, J., Tan, H. Y., Nesic, O., Hargett, G. L., Bopp, A. C., Yamani, A., Lin, Q., Willis, W. D., and
Hulsebosch, C. E. (2009). Peripheral and central sensitization in remote spinal cord regions contribute to central neuropathic pain after spinal cord injury. Pain 147, 265-276.

Chaovipoch, P., Jelks, K. A., Gerhold, L. M., West, E. J., Chongthammakun, S., and Floyd, C. L. (2006). 17betaestradiol is protective in spinal cord injury in post- and pre-menopausal rats. J. Neurotrauma 23, 830-852.

Chen, Y., Chen, C., and Liu-Chen, L. Y. (2007). Dynorphin peptides differentially regulate the human kappa opioid receptor. Life Sci. 80, 1439-1448.

Cho, H. J., and Basbaum, A. I. (1989). Ultrastructural analysis of dynorterminals in the superficial dorsal horn of the deafferented spinal cord of the rat. J. Comp. Neurol. 281, 193-205.

Cothron, K. J., Massey, J. M., Onifer, S. M., and Hubscher, C. H. (2008). Identification of penile inputs to the rat gracile nucleus. Am. J. Physiol. Regul. Integr. Comp. Physiol. 294, R1015-R1023.

Crown, E. D., Gwak, Y. S., Ye, Z., Johnson, K. M., and Hulsebosch, C. E. (2008). Activation of p38 MAP kinase is involved in central neuropathic pain following spinal cord injury. Exp. Neurol. 213, 257-267. phin B-immunoreactive cells and

menopause suggesting that decreased estrogen levels may play a role in its pathogenesis (Waxman and Zatzkis, 1986), which is consistent with the argument that the beneficial outcomes result from estrogen replacement.

Also, since increased microglial activity may produce adverse effects on spinal cord circuitries, which is indicated by the temporal correlation between abnormal pain response and the proliferation of Iba-1 positive microglia in spinal cord dorsal horn in a sciatic nerve injury model of neuropathic pain (Echeverry et al., 2008), the potential beneficial effect of EB may be due to the suppression of adverse microglial activity. This is suggested by the effect of EB pretreatment on a culture of microglia activated by lipopolysaccharide (LPS), which prevents injury produced in the rat mesencephalic primary neuron culture by the conditioned media from LPS treated microglial culture (Liu et al., 2005).

\section{ACKNOWLEDGMENTS}

We thank James Armstrong, Jason Fell and Christine Nunn for excellent technical assistance. Special thanks to Dr. Ashok Kumar for his assistance with Western blot, Dr. Martha Bickford and Ms. Cathie Caple for their assistance with the electron microscopy, and Darlene Burke for her assistance with statistical analysis. This study was supported by grant RR015576 from NCRR, a component of $\mathrm{NIH}$. The authors have no conflict of interest with regards to the present study.

Dantas, A. P., Tostes, R. C., Fortes, Z. B., Costa, S. G., Nigro, D., and Carvalho, M. H. (2002). In vivo evidence for antioxidant potential of estrogen in microvessels of female spontaneously hypertensive rats. Hypertension 39, 405-411.

De Camilli, P., Cameron, R., and Greengard, P. (1983). Synapsin I (protein I), a nerve terminal-specific phosphoprotein. I. Its general distribution in synapses of the central and peripheral nervous system demonstrated by immunofluorescence in frozen and plastic sections. J. Cell Biol. 96, 1337-1354.

de Groat, W. C. (1998). Anatomy of the central neural pathways controlling the lower urinary tract. Eur. Urol. 34(Suppl. 1), 2-5.

Diamond, B., and Yelton, D. E. (1981) A new Fc receptor on mouse macrophages binding IgG3. J. Exp. Med. 153, 514-519.

Dogra, C., Changotra, H., Wergedal, J. E., and Kumar, A. (2006). Regulation of phosphatidylinositol 3-kinase (PI3K)/Akt and nuclear factor-kappa B signaling pathways in dystrophin-deficient skeletal muscle in response to mechanical stretch. J. Cell. Physiol. 208, 575-585.

Echeverry, S., Shi, X. Q., and Zhang, J. (2008). Characterization of cell proliferation in rat spinal cord following peripheral nerve injury and the relationship with neuropathic pain. Pain 135, 37-47.

Faden, A. I., Molineaux, C. J., Rosenberger, J. G., Jacobs, T. P., and Cox, B. M. (1985). Increased dynorphin immunoreactivity in spinal cord after traumatic injury. Regul. Pept. 11, 35-41.

Fremeau, R. T. Jr., Voglmaier, S., Seal, R. P., and Edwards, R. H. (2004). VGLUTs define subsets of excitatory neurons and suggest novel roles for glutamate. Trends Neurosci. 27, 98-103.

Gintzler, A. R., Schnell, S. A., Gupta, D. S., Liu, N. J., and Wessendorf, M. W. (2008). Relationship of spinal dynorphin neurons to delta-opioid receptors and estrogen receptor alpha: anatomical basis for ovarian sex steroid opioid antinociception. J. Pharmacol. Exp. Ther. 326, 725-731.

Goldstein, A., and Ghazarossian, V. E. (1980). Immunoreactive dynorphin in pituitary and brain. Proc. Natl. Acad. Sci. U.S.A. 77, 6207-6210.

Gottsch, M. L., Navarro, V. M., Zhao, Z., Glidewell-Kenney, C., Weiss, J., Jameson, J. L., Clifton, D. K., Levine, J. E., and Steiner, R. A. (2009). Regulation of Kiss 1 and dynorphin gene expression in the murine brain by classical and nonclassical estrogen receptor pathways. J. Neurosci. 29, 9390-9395. 
Guillery, R. W. (2000). Early electron microscopic observations of synaptic structures in the cerebral cortex: a view of the contributions made by George Gray (1924-1999). Trends Neurosci. 23, 594-598.

Hall, B. J., Lally, J. E., Vukmanic, E. V., Armstrong, J. E., Fell, J. D., Gupta, D. S., and Hubscher, C. H. (2010). Spinal cord injuries containing asymmetrical damage in the ventrolateral funiculus is associated with a higher incidence of at-level allodynia. J. Pain. 11, 864-875.

Honore, P., Rogers, S. D, Schwei, M. J., Salak-Johnson, J. L., Luger, N. M., Sabino, M. C., Clohisy, D. R., and Mantyh, P. W.(2000). Murine models of inflammatory, neuropathic and cancer pain each generates a unique set of neurochemical changes in the spinal cord and sensory neurons. Neuroscience 98, 585-598.

Hubscher, C. H., Fell, J. D., and Gupta, D. S. (2010). Sex and hormonal variations in the development of at-level allodynia in a rat chronic spinal cord injury model. Neurosci. Lett. 477, 153-156.

Hubscher, C. H., and Johnson, R. D. (1999). Changes in neuronal receptive field characteristics in caudal brain stem following chronic spinal cord injury. J. Neurotrauma 16, 533-541.

Hubscher, C. H., and Johnson, R. D. (2006). Chronic spinal cord injury induced changes in the responses of thalamic neurons. Exp. Neurol. 197, 177-188.

Hubscher, C. H., Kaddumi, E. G., and Johnson, R. D. (2008). Segmental neuropathic pain does not develop in male rats with complete spinal transections. J. Neurotrauma 25, 1241-1245.

Jansen, A. S., Farwell, D. G., and Loewy, A. D. (1993). Specificity of pseudorabies virus as a retrograde marker of sympathetic preganglionic neurons: implications for transneuronal labeling studies. Brain Res. 617, 103-112.

Jiao, Y., Sun, Z., Lee, T., Fusco, F. R., Kimble, T. D., Meade, C. A., Cuthbertson, S., and Reiner, A. (1999). A simple and sensitive antigen retrieval method for free-floating and slidemounted tissue sections. J. Neurosci. Methods 93, 149-162.

Kachadroka, S., Hall, A. M., Niedzielko, T. L., Chongthammakun, S., and Floyd, C. L. (2010). Effect of endogenous androgens on 17betaestradiol-mediated protection after spinal cord injury in male rats. $J$. Neurotrauma 27, 611-626.
Kalra, S. P., and Kalra, P. S. (1974). Temporal interrelationships among circulating levels of estradiol, progesterone and $\mathrm{LH}$ during the rat estrous cycle: effects of exogenous progesterone. Endocrinology 95, 1711-1718.

Kramer, P. R., and Bellinger, L. L. (2009). The effects of cycling levels of 17beta-estradiol and progesterone on the magnitude of temporomandibular joint-induced nociception. Endocrinology 150, 3680-3689.

Lai, J., Luo, M. C., Chen, Q., Ma, S., Gardell, L. R., Ossipov, M. H., and Porreca, F. (2006). Dynorphin A activates bradykinin receptors to maintain neuropathic pain. Nat. Neurosci. 9, 1534-1540.

Lau, C. G., and Zukin, R. S. (2007). NMDA receptor trafficking in synaptic plasticity and neuropsychiatric disorders. Nat. Rev. Neurosci. 8, 413-426.

Laughlin, T. M., Larson, A. A., and Wilcox, G. L. (2001). Mechanisms of induction of persistent nociception by dynorphin. J. Pharmacol. Exp. Ther. 299, 6-11.

Laughlin, T. M., Vanderah, T. W., Lashbrook, J., Nichols, M. L., Ossipov, M., Porreca, F., and Wilcox, G. L. (1997). Spinally administered dynorphin A produces long-lasting allodynia: involvement of NMDA but not opioid receptors. Pain 72, 253-260.

Levi, R., Hultling, C., and Seiger, A. (1995). The Stockholm spinal cord injury study. 3. Health-related issues of the Swedish annual level-of-living survey in SCI subjects and controls. Paraplegia 33, 726-730.

Lin, J. Y., Cheng, Y. C., Chen, J. Y., Chien, C. C., Lin, S. C., Wen, Y. R., Tsou, T. S., and Ling, Q. D. (2010). Increased spinal prodynorphin gene expression in reinflammation-associated hyperalgesia after neonatal inflammatory insult. BMC Neurosci. 11, 139. doi:10.1186/1471-2202-11-139

Liu, X., Fan, X. L., Zhao, Y., Luo, G. R., Li, X. P., Li, R., and Le, W. D. (2005). Estrogen provides neuroprotection against activated microglia-induced dopaminergic neuronal injury through both estrogen receptor-alpha and estrogen receptor-beta in microglia. J. Neurosci. Res. 81, 653-665.

Long, J. B., Petras, J. M., Mobley, W. C., and Holaday, J. W. (1988). Neurological dysfunction after intrathecal injection of dynorphin A (1-13) in the rat. II. Nonopioid mechanisms mediate loss of motor, sensory and autonomic function. J. Pharmacol. Exp. Ther. 246, 1167-1174.
Malan, T. P., Ossipov, M. H., Gardell, L. R., Ibrahim, M., Bian, D., Lai, J., and Porreca, F. (2000). Extraterritorial neuropathic pain correlates with multisegmental elevation of spinal dynorphin in nerve-injured rats. Pain 86, 185-194.

Marvizon, J. C., Chen, W., and Murphy, N. (2009). Enkephalins, dynorphins, and beta-endorphin in the rat dorsal horn: an immunofluorescence colocalization study. J. Comp. Neurol. 517, 51-68.

McLaughlin, B. J., Barber, R., Saito, K., Roberts, E., and $\mathrm{Wu}, \mathrm{J}$. Y. (1975). Immunocytochemical localization of glutamate decarboxylase in rat spinal cord. J. Comp. Neurol. 164, 305-321.

McLaughlin, J. P., Xu, M., Mackie, K. and Chavkin, C. (2003). Phosphorylation of a carboxyl-terminal serine within the kappa-opioid receptor produces desensitization and internalization. J. Biol. Chem. 278, 34631-34640.

Millan, M. J., Millan, M. H., Pilcher, C. W., Czlonkowski, A., Herz, A., and Colpaert, F. C. (1985). Spinal cord dynorphin may modulate nociception via a kappa-opioid receptor in chronic arthritic rats. Brain Res. 340 156-159.

Nequin, L. G., Alvarez, J., and Schwartz, N. B. (1979). Measurement of serum steroid and gonadotropin levels and uterine and ovarian variables throughout 4 day and 5 day estrous cycles in the rat. Biol. Reprod. 20, 659-670.

Paxinos, G., and Watson, C. (1998). The Rat Brain in Stereotaxic Coordinates. San Diego: Academic Press.

Perney, T. M., Hirning, L. D., Leeman, S. E., and Miller, R. J. (1986). Multiple calcium channels mediate neurotransmitter release from peripheral neurons. Proc. Natl. Acad. Sci. U.S.A. 83, 6656-6659.

Persson, S., Schafer, M. K., Nohr D., Ekstrom, G., Post, C., Nyberg, F., and Weihe, E. (1994). Spinal prodynorphin gene expression in collagen-induced arthritis: influence of the glucocorticosteroid budesonide. Neuroscience 63, 313-326.

Pickar, J. H., MacNeil, T., and Ohleth, K. (2010). SERMs: progress and future perspectives. Maturitas 67, 129-138.

Przewlocki, R., Haarmann, I., Nikolarakis, K., Herz, A., and Hollt, V. (1988). Prodynorphin gene expression in spinal cord is enhanced after traumatic injury in the rat. Brain Res. 464, 37-41.

Reed, W. R., Chadha, H. K., and Hubscher, C. H. (2009). Effects of 17beta-estradiol on responses of viscerosomatic convergent thalamic neurons in the ovariectomized female rat. J. Neurophysiol. 102, 1062-1074.

Ritz, M. F., and Hausmann, O. N. (2008). Effect of 17beta-estradiol on functional outcome, release of cytokines, astrocyte reactivity and inflammatory spreading after spinal cord injury in male rats. Brain Res. 1203, 177-188.

Samuel, C. S., Coghlan, J. P., and Bateman, J. F. (1998). Effects of relaxin, pregnancy and parturition on collagen metabolism in the rat pubic symphysis. J. Endocrinol. 159, 117-125.

Santmyire, B. R., Venkat, V., Beinder, E., and Baylis, C. (2010). Impact of the estrus cycle and reduction in estrogen levels with aromatase inhibition, on renal function and nitric oxide activity in female rats. Steroids 75 , 1011-1015.

Sayed, Y., and Taxel, P. (2003). The use of estrogen therapy in men. Curr. Opin. Pharmacol. 3, 650-654.

Scheff, S. W., Rabchevsky, A. G., Fugaccia, I., Main, J. A., and Lumpp, J. E. Jr. (2003). Experimental modeling of spinal cord injury: characterization of a force-defined injury device. $J$. Neurotrauma 20, 179-193.

Sharma, H. S., Nyberg, F., and Olsson, Y. (1992). Dynorphin A content in the rat brain and spinal cord after a localized trauma to the spinal cord and its modification with p-chlorophenylalanine. An experimental study using radioimmunoassay technique. Neurosci. Res. 14, 195-203.

Siddall, P. J., Xu, C. L., Floyd, N., and Keay, K. A. (1999). C-fos expression in the spinal cord of rats exhibiting allodynia following contusive spinal cord injury. Brain Res. 851, 281-286.

Siegel, S., and Castellano, J. Jr. (1988). Nonparametric Statistics for the Behavioral Sciences. Boston: McGraw-Hill.

Skilling, S. R., Sun, X., Kurtz, H. J., and Larson, A. A. (1992). Selective potentiation of NMDA-induced activity and release of excitatory amino acids by dynorphin: possible roles in paralysis and neurotoxicity. Brain Res. 575, 272-278.

Spampinato, S., Canossa, M., Campana, G., Carboni, L., and Bachetti, T. (1995). Estrogen regulation of prodynorphin gene expression in the rat adenohypophysis: effect of the antiestrogen tamoxifen. Endocrinology 136, 1589-1594.

Sribnick, E. A., Matzelle, D. D., Ray, S. K., and Banik, N. L. (2006). Estrogen treatment of spinal cord 
injury attenuates calpain activation and apoptosis. J. Neurosci. Res. 84, 1064-1075.

Tachibana, T., Miki, K., Fukuoka, T., Arakawa, A., Taniguchi, M., Maruo, S., and Noguchi, K. (1998). Dynorphin mRNA expression in dorsal horn neurons after traumatic spinal cord injury: temporal and spatial analysis using in situ hybridization. J. Neurotrauma 15, 485-494.

Tang, Q., Lynch, R. M., Porreca, F., and Lai, J. (2000). Dynorphin A elicits an increase in intracellular calcium in cultured neurons via a nonopioid, non-NMDA mechanism. $J$. Neurophysiol. 83, 2610-2615.

Todd, A. J. (2002). Anatomy of primary afferents and projection neurones in the rat spinal dorsal horn with particular emphasis on substance $\mathrm{P}$ and the neurokinin 1 receptor. Exp. Physiol. 87, 245-249.

Vaeroy, H., Nyberg, F., and Terenius, L. (1991). No evidence for endorphin deficiency in fibromyalgia following investigation of cerebrospinal fluid (CSF) dynorphin A and Met-enkephalin-Arg6-Phe7. Pain 46, 139-143.

Vanderah, T. W., Laughlin, T., Lashbrook, J. M., Nichols, M. L., Wilcox,
G. L., Ossipov, M. H., Malan, T. P. Jr., and Porreca, F.(1996). Single intrathecal injections of dynorphin A or des-Tyr-dynorphins produce long-lasting allodynia in rats: blockade by MK- 801 but not naloxone. Pain 68, 275-281.

Wang, Z., Gardell, L. R., Ossipov, M. H., Vanderah, T. W., Brennan, M. B., Hochgeschwender, U., Hruby, V. J., Malan, T. P. Jr., Lai, J., and Porreca, F.(2001). Pronociceptive actions of dynorphin maintain chronic neuropathic pain. J. Neurosci. 21, 1779-1786.

Waxman, J., and Zatzkis, S. M. (1986). Fibromyalgia and menopause. Examination of the relationship. Postgrad. Med. 80, 165-167, 70-71.

Weaver, C. E. Jr., Park-Chung, M., Gibbs, T. T., and Farb, D. H. (1997). 17betaEstradiol protects against NMDAinduced excitotoxicity by direct inhibition of NMDA receptors. Brain Res. 761, 338-341.

Webb, A. A., Chan, C. B., Brown, A., and Saleh, T. M. (2006). Estrogen reduces the severity of autonomic dysfunction in spinal cord-injured male mice. Behav. Brain Res. 171, 338-349.
Widerstrom-Noga, E. G., FelipeCuervo, E., Broton, J. G., Duncan, R. C., and Yezierski, R. P. (1999). Perceived difficulty in dealing with consequences of spinal cord injury. Arch. Phys. Med. Rehabil. 80, 580-586.

Woods, A. S., Kaminski, R., Oz, M. Wang, Y., Hauser, K., Goody, R., Wang, H. Y., Jackson, S. N., Zeitz, P., Zeitz, K. P., Zolkowska, D., Schepers, R., Nold, M., Danielson, J., Gräslund, A., Vukojevic, V., Bakalkin, G., Basbaum, A., and Shippenberg, T. (2006). Decoy peptides that bind dynorphin noncovalently prevent NMDA receptor-mediated neurotoxicity. J. Proteome Res. 5, 1017-1023.

Yune, T. Y., Kim, S. J., Lee, S. M., Lee, Y. K., Oh, Y. J., Kim, Y. C., Markelonis, G. J., and Oh, T. H. (2004). Systemic administration of 17beta-estradiol reduces apoptotic cell death and improves functional recovery following traumatic spinal cord injury in rats. J. Neurotrauma 21, 293-306.

Zhang, R. X., Ruda, M. A., and Qiao, J. T. (1998). Pre-emptive intrathecal Mk801, a non-competitive N-methylD-aspartate receptor antagonist, inhibits the up-regulation of spinal dynorphin mRNA and hyperalgesia in a rat model of chronic inflammation. Neurosci. Lett. 241, 57-60.

Conflict of Interest Statement: The authors declare that the research was conducted in the absence of any commercial or financial relationships that could be construed as a potential conflict of interest.

Received: 15 December 2011; paper pending published: 09 January 2012; accepted: 04 February 2012; published online: 22 February 2012.

Citation: Gupta DS and Hubscher CH (2012) Estradiol treatment prevents injury induced enhancement in spinal cord dynorphin expression. Front. Physio. 3:28. doi: 10.3389/fphys.2012.00028

This article was submitted to Frontiers in Integrative Physiology, a specialty of Frontiers in Physiology.

Copyright () 2012 Gupta and Hubscher. This is an open-access article distributed under the terms of the Creative Commons Attribution Non Commercial License, which permits non-commercial use, distribution, and reproduction in other forums, provided the original authors and source are credited. 